\title{
The Effects of Polymeric Zinc Propylen-Bis-Dithiocarbamate (Propineb) on Tooth Development in Rats
}

\author{
Efectos del Propileno-Bis-Ditiocarbamato de Zinc Polimérico (Propineb) \\ sobre el Desarrollo de los Dientes en Ratas
}

Koparal Mahmut*; Er Faruk ${ }^{* *}$; Deveci Engin ${ }^{* * *}$ \& Yavuz Dilek ${ }^{* * *}$

MAHMUT, K.; FARUK, E.; ENGIN, D. \& DILEK,Y. The effects of polymeric zinc propylen-bis-dithiocarbamate (Propineb) on tooth development in rats. Int. J. Morphol., 33(1):85-88, 2015.

SUMMARY: Dithiocarbamate propinebs are organometal fungicides that are widely used for the control of diseases in plants. In this study, pregnant female rats received $400 \mathrm{ppm}$ propineb concentrations in $5 \mathrm{ml}$ distilled water for 16 days of gestation, and then infant rats were obtained by cesarean section. In the histological analysis on the frontal sections, the use of propineb was found effective on odontoblast cell hyperplasia, cell infiltration in the dental papilla, and degeneration in the mesenchymal cells of the outer enamel. The expression of MMP-2 (Matrix Metalloproteinase-2) and VEGF (Endothelial cell growth factor) in the connective tissue was evaluated by immunohistochemistry. The drinking water given to the mothers in propineb tooth bud, enamel and dentin, resulted in morphological changes suggestive of a delay in formation, which cross the placental barrier and possibly affect the tooth development.

KEY WORDS: Propineb; MMP2; Tooth buds; VEGF.

\section{INTRODUCTION}

Polymeric zinc propylen-bis-dithiocarbamate (Propineb) is a compound widely used in fruit and vegetables cultures due to its large spectrum of activity against fungal plant diseases (IPCS, 1998). Data from animal models suggest that the restriction of dietary zinc increases the incidence of dental caries, reducing the lipid content of developing enamel and causing morphological alterations in ameloblasts (Cerklewski 1981). Tooth development is highly regulated through a series of reciprocal and sequential epithelial-mesenchymal interactions that lead to cuspal morphogenesis, cell differentiation, and the subsequent formation of the specialized matrices of enamel, dentin, cementum, and bone (Kollar \& Mina, 1991; Bleicher et al., 1999; Fincham et al., 1999; Hu et al., 2000). During the odontoblastic processes, MMP-2 may be concentrated in an area adjacent to the dentino-enamel junction and, in this way, may contribute to these processes (Goldberg et al., 2003). Vascular endothelial growth factor (VEGF) potently regulates the formation of new blood vessels through VEGF receptors and has been reported to be a key factor in periodontal angiogenesis during tooth movement (Miyagawa et al., 2009). The purpose of this study is to investigate the histopathologic and molecular changes taking place in the early stages of tooth eruption in the infant rats whose mothers have been treated with propineb during pregnancy.

\section{MATERIAL AND METHOD}

The study protocol was approved by the Animal Research committee of Dicle University (DUHADEK), Turkey. Twenty pregnant female Wistar albino rats weighing 200-230 g were divided into two groups (six animals for each exposure group and six females used as control). Females were mated with non-exposed males; the criterion used to identify mated females was the presence of spermatozoa in the vagina (day 0 of gestation). All pregnant females were individually housed in stainless steel cages at room temperature. All of them were treated with propineb for 16 days, and mandibular regions of litter rats were sacrificed on the first day of birth. The control group received

\footnotetext{
* Department of Maxillofacial Surgery, Faculty of Dentistry, University of Dicle, Diyarbakir, Turkey.

** Department of Restorative Dentistry, Faculty of Dentistry, Near East University, North Cyprus, Turkey. atillakaan@ gmail.com

*** Department of Histology and Embryology, Faculty of Medicine, University of Dicle, Diyarbakir, Turkey.
} 
only distilled water. The doses administered orally by gastric tube (helping toxicant injections orally) were calculated on the basis of initial body weight of each animal (ppm=mg toxicant per $1 \mathrm{~kg}$ body weight). The samples were placed in $10 \%$ formaldehyde and dehydrated in 70-100\% ethanol series. They were then placed in paraffin baths at $58^{\circ} \mathrm{C}$ for paraffin inclusion. The sections of 4-6 $\mu \mathrm{m}$ were prepared from paraffin blocks using a rotary microtome. These sections were then stained with Trichrom mason.

Immunohistochemical analysis of MMP2 and VEGF. Antigen retrieval process was performed twice in citrate buffer solution ( $\mathrm{pH}$ : 6.0); the first for 7 minutes, and the latter was boiled in microwave oven at $700 \mathrm{~W}$ for 5 minutes. They were allowed to cool to room temperature for 30 minutes and washed twice in distilled water for 5 minutes. Endogenous peroxidase activity was blocked in $0.1 \%$ hydrogen peroxide for 20 minutes. Ultra V block (Cat.No:859043, Invitrogen, Carlsbad, CA,USA) was applied for 10 minutes prior to the application of primary antibodies and polyclonal antibody against MMP-2 (1/200) (Neomarkers Co., Inc., USA) (vWF antibody, rabbit-anti-vWF, 1/ 800,ab6994, Abcam) overnight. Secondary antibody was applied for 20 minutes. The slides were then exposed to streptavidin-peroxidase for 20 minutes. As a chromogen, diaminobenzidine (DAB: Invitrogen, Carlsbad, CA, USA) was used. The control slides were prepared as mentioned above with the omission of primary antibodies. After counterstaining with hematoxylin and washing in tap water for 8 minutes and in distilled water for 10 minutes, the slides were mounted with entellan.

\section{RESULTS AND DISCUSSION}

At 16 day intrauterine life, morphogenesis proceeds as the epithelial cells proliferate and form the enamel organ surrounding the mesenchymal dental papilla and the tooth germ in the cap stage. The transition from bud to cap stage is characterized by the development of the cervical area. The dental epithelium appears, and the horseshoe-shaped dental lamina generates the future dental arches at the late cap stage. The dental mesenchyme cells that are condensed around the bud formed the dental papilla between the dental follicles surrounding the epithelium. The external dental epithelium was formed by several layers of cubical cells and the internal dental epithelium by only one layer (Fig. 1A). The histological analysis on the frontal sections revealed that the use of propineb is effective on the development of odontoblast cell hyperplasia, cell infiltration in the dental papilla, and degeneration in the mesenchymal cells of the outer enamel (Fig. 1B). In the control group, significant MMP2 expression was observed in the dental follicle, dental lamina, odontoblasts and enamel epithelium as well as in the Mandibular cartilage (Fig. 1C). MMP2 expression in the group treated with propineb was localized to the dental lamina. MMP2 was expressed in the fibroblasts of dental follicles. However, only a few cells that expressed MMP-2 were found in odontoblast cells. Also, the MMP2 expression was found negative in Mandibular cartilage (Fig. 1D). Dental papilla and dental follicle region close to the odontoblastic intense expression was observed in the endothelium of the vessels (Fig. 1E).

Propineb is reported to affect the development of animals through its zinc effect by crossing the placental barrier during the embryonic and fetal periods (Guven et al., 1998). Female rats were exposed orally to propineb concentrations of 200 and $400 \mathrm{ppm}$, from the 6th day of gestation up to birth. At $400 \mathrm{ppm}$, propineb showed a variety of macroscopic (e.g. ptosis and paralysis) and microscopic symptoms in the organs of both fetuses and female rats. We found that the body weights of both one-day old litters and their propineb-treated mothers were lower than those of the controls. Propineb was found to cause diarrhea in the pregnant female rats, which is a well-known clinical picture for acute Zn overload (Goyer, 1986). This may be one reason for the weight loss observed in female rats. In our study, during the 16-day intrauterine life, the use of propineb was found effective on odontoblast cell hyperplasia, cell infiltration in the dental papilla, and degeneration in the mesenchymal cells of the outer enamel (Fig. 1B). Reponen et al. (1992) demonstrated that MMP-2 is expressed in the mesenchyme of developing organs including early developmental stages of the tooth, and it is strongly upregulated in differentiated odontoblasts at the time of basement membrane degradation. Development of teeth is regulated by interactions between the epithelial and underlying mesenchymal tissues. In our study, the increased MMP2 in the odontoblasts and dental papilla during the cap stage of tooth development was found effective on the formation of collagen in the basement membrane deposition of dentin (Fig. 1C). However, in the group treated with propineb, the MMP2 expression was significant in the dental papilla, and weak odontoblastic enamel expression was observed in the epithelium (Fig. 1D). In the developing tooth, VEGF and VEGFR-2 are expressed in odontoblasts and the inner enamel epithelium may regulate odontoblast development and the differentiation of inner enamel epithelium to ameloblasts (Aida et al., 2005; Miwa et al., 2008) VEGF expression in pulp fibroblasts and odontoblasts of human teeth is higher in immature than mature permanent teeth, suggesting a role of VEGF in tooth maturation (Wang et al., 2007). In the enamel knot cells that were visible in a developing tooth germ during the late cap stage, the expression was weaker than in the control group. 


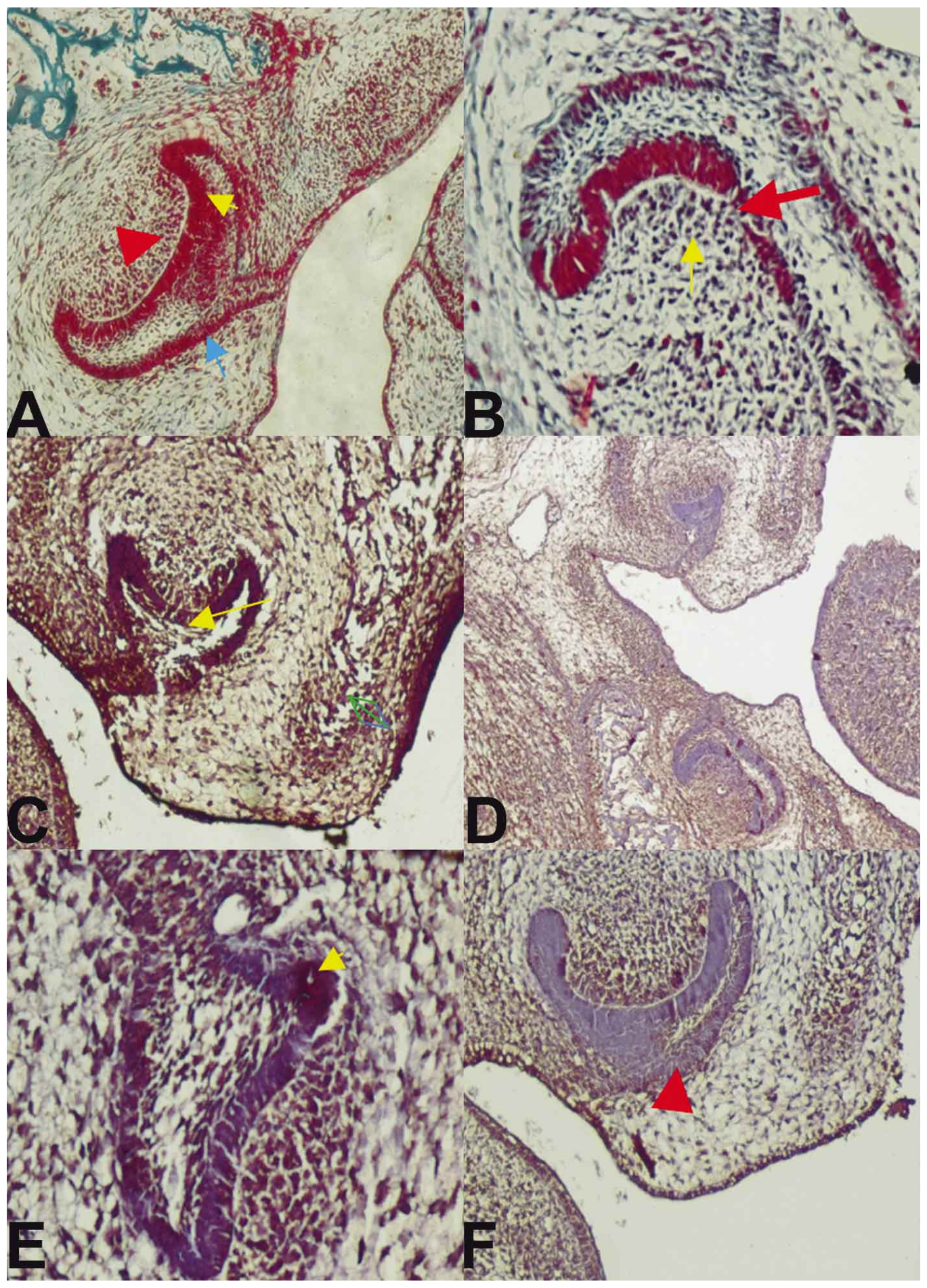

Fig. 1. A) Control group:Ameloblasts (blue arrow), odontoblasts (yellow arrow), dental papilla mesenchymal cells (red arrow) in the normal developmental differentiation. B) Propineb group; Hyperplasia of odontoblast cells (yellow arrow),increase in the mesensimal cells of dental papilla, outer enamel epithelium of the sheath where it is associated with degeneration (red arrow). C) A increase the dental follicle, dental lamina, odontoblasts and enamel epithelium, also in the mercel cartilage (gren arrow). D) Propineb group; Intense expression in mesenchymal cells in the dental papilla (yellow arrow). E) Dental papilla and dental follicle region close to the odontoblast intense expression of vascular endothelial (yellow arrow). F) VEGF negative of expression endothel cells in blood (F) Enamel knots cells visible in a developing tooth germ in the late cap stage (red arrow). 
CONCLUSIONS. We conclude that, depending on its zinc effect, the Propineb is an effective on the ectoderm cells during the formation of enamel and on the mesenchyme cells during the formation of dental papilla, as well as causing structural changes, a delay in the development of extracellular matrix, and a recession in dental development.

MAHMUT, K.; FARUK, E.; ENGIN, D. \& DILEK,Y. Efectos del propileno-bis-ditiocarbamato de zinc polimérico (Propineb) sobre el desarrollo de los dientes en ratas. Int. J. Morphol., 33(1):85-88, 2015.

RESUMEN: Los ditiocarbamatos (Propineb) son fungicidas organometálicos que son ampliamente utilizados para el control de enfermedades en las plantas. En este estudio, ratas hembras preñadas recibieron concentraciones de $4000 \mathrm{ppm}$ de propineb en $5 \mathrm{ml}$ de agua destilada durante 16 días de su gestación. Luego, las crías de las ratas fueron obtenidas mediante cesárea para su estudio estudio histológico. En el análisis histológico de las secciones frontales, el uso de propineb fue positivo para la hiperplasia de las células odontoblástica, infiltración de células en la papila dental, y la degeneración en las células mesenquimales del epitelio externo del esmalte. La expresión de MMP-2 (metaloproteinasa de la matriz 2) y VEGF (factor de crecimiento de células endoteliales) en el tejido conectivo se evaluó por inmunohistoquímica. El agua potable con propineb dada a las madres actuó sobre el brote dentario, esmalte y dentina; se tradujo en cambios morfológicos indicativos de un retraso en la formación. Por tanto, el propineb atraviesa la barrera placentaria y posiblemente afecten el desarrollo de los dientes.

PALABRAS CLAVE: Propineb; MMP2; Brotes dentarios; VEGF.

\section{REFERENCES}

Aida, M.; Irié, T.; Aida, T. \& Tachikawa, T. Expression of protein kinases $\mathrm{C}$ betaI, betaII, and VEGF during the differentiation of enamel epithelium intooth development. J. Dent. Res., 84(3):234-9, 2005.

Bleicher, F.; Couble, M. L.; Farges, J. C.; Couble, P. \& Magloire, H. Sequential expression of matrix protein genes in developing rat teeth. Matrix Biol., 18(2):133-43, 1999.

Cerklewski, F. L. Effect of suboptimal zinc nutrition during gestation and lactation on rat molar tooth composition and dental caries. J. Nutr., 111(10):1780-3, 1981.

Fincham, A. G.; Moradian-Oldak, J. \& Simmer, J. P. The structural biology of the developing dental enamel matrix. J. Struct. Biol., 126(3):270-99, 1999.

Goldberg, M.; Septier, D.; Bourd, K.; Hall, R.; George, A.; Goldberg, H. \& Menashi, S. Immunohistochemical localization of MMP-2, MMP-9, TIMP-1, and TIMP-2 in the forming rat incisor. Connect. Tissue Res., 44(3-4):143-53, 2003.

Goyer, R. A. Toxic effects of metals. In: Klaassen, C. D.; Amdur, M. O. \& Doull, J. Casarett \& Doul's Toxicology: The basic science of posions. 3rd ed. New York, Macmillan Publishing Co., 1986. pp. 623-80.

Guven, K.; Deveci, E.; Akba, O.; Onen, A. \& de Pomerai, D. The accumulation and histological effects of organometallic fungicides Propineb and Maneb in the kidneys of fetus and female rats during pregnancy. Toxicol. Lett., 99(2):91-8, 1998.

Hu, C. C.; Hart, T. C.; Dupont, B. R.; Chen, J. J.; Sun, X.; Qian, Q.; Zhang, C. H.; Jiang, H.; Mattern, V. L.; Wright, J. T. \& Simmer, J. P. Cloning human enamelin cDNA, chromosomal localization, and analysis of expression during tooth development. J. Dent. Res., 79(4):912-9, 2000.
International Programme on Chemical Safety (IPCS). Dithiocarbamate pesticides, ethylenthiourea and propilenthiourea: a general introduction. Environmental Health Criteria 78, 1998. Disponible en: http:// www.inchem.org/documents/ehc/ehc/ehc78.htm

Kollar, E. J. \& Mina, M. Role of the early epithelium in the patterning of the teeth and Meckel's cartilage. J. Craniofac. Genet. Dev. Biol., 11(4):223-8, 1991.

Miwa, Y.; Fujita, T.; Sunohara, M. \& Sato, I. Immunocytochemical localization of vascular endothelial growth factor and vascular endothelial growth factor receptor- 2 of the human deciduous molar tooth germ development in the human fetus. Ann. Anat., 190(3):246-51, 2008.

Miyagawa, A.; Chiba, M.; Hayashi, H. \& Igarashi, K. Compressive force induces VEGF production in periodontal tissues. J. Dent. Res., 88(8):752-6, 2009.

Reponen, P.; Sahlberg, C.; Huhtala, P.; Hurskainen, T.; Thesleff, I. \& Tryggvason, K. Molecular cloning of murine 72-kDa type IV collagenase and its expression during mouse development. J. Biol. Chem., 267(11):7856-62, 1992.

Wang, Q.; Lin, X. J.; Lin, Z. Y.; Liu, G. X. \& Shan, X. L. Expression of vascular endothelial growth factor in dental pulp of immature and mature permanent teeth in human. Shanghai Kou Qiang Yi Xue, 16(3):285-9, 2007.

\section{Correspondence to: \\ Engin Deveci \\ Dicle University, Medical Faculty Histology and Embryology Dept. 21280 Diyarbakir TURKEY}

Received: 17-07-2014 Accepted: $27-10-2014$
Email:engindeveci64@gmail.com 